\title{
Rock Physical Experimental Research in Tanan Volcanic Rock Reservoir
}

\author{
Lailin Li ${ }^{1}$, Haibo Zhao' ${ }^{1}$ Xuehui Han ${ }^{2}$ \\ ${ }^{1}$ Oil Exploration and Development Research Institute of Daqing, Daqing, China \\ ${ }^{2}$ China University of Petroleum (East China), Qingdao, China \\ Email: lill@petrochina.com.cn
}

Received November 2013

\begin{abstract}
Under the condition of simulated formation temperature and pressure, the compression and shear wave velocity of the tuffaceous conglomerates and rock-fragment sandstones of the reservoirs in K1t, k1n group of Cretaceous system in Tanan are measured. The effects of lithology, mineral content, density, porosity, shale content, and water saturation on the acoustic velocity of the athrogenic rock are studied. Within the limits of our observation, some rules are found: (1) the velocity of the fine tuffaceous conglomerates is remarkably greater than that of the tuffaceous rock-fragment sandstones with good physical property; (2) the compression velocity increases with fragment content, and decreases with quartz and feldspar content in the mud; (3) the compression velocity increases with density, especially, in tuffaceous rock-fragment sandstones, the velocity keeps a good relation with density in form of power function; (4) compression and shear wave velocity decreases with porosity and shale content, velocity of the tuffaceous rock-fragment sandstones keeps a good relation with porosity and shale content in form of negative linear function, but effects of shale content is only $1 / 5$ to $1 / 10$ of that of the porosity, hence can be neglected; (5) with porosity increases, compression wave velocity is relatively sensitive to fluid alternation, and the rang in which velocity varies keeps positive correlation with porosity. The result provides a foundation for the research of seismic and logging data evaluation approaches in athrogenic rock reservoirs, Haita basin.
\end{abstract}

\section{Keywords}

Tuffaceous Rock-Fragment Sandstones, Acoustic Velocity, Porosity, Shale Content, Density, Water Saturation

\section{Introduction}

Haita Basin is a part of Central Asia-Ancient Aulacogen, which belongs to Eergu'Na-Greater Khingan Range tectonic zone. Tongbomiao Formation and Nantun Formation in the lower Cretaceous of Zhalainuoer group develop a large number of oil-bearing tight tuffaceous conglomerate and medium to low porosity and permeability rock-fragment sandstone reservoirs, which forms the main area for improving the production and has great po- 
tential for prospecting [1]. At present, due to the lack of adequate understanding of the factors that affect the velocity of the volcano clastic rock in Haita Basin, the seismic and logging data can't be applied to predict the lithology of rock, calculate the porosity and detect the oil and gas effectively. Therefore, a detailed research on the influencing factors of velocity in the volcano clastic rock in Haita Basin is needed.

Until now, many researches have been done on the velocity properties and influencing factors of velocity (lithology, physical properties, fluid properties, density and environmental factors) in the sedimentary reservoirs. For instance, Wyllie (1956) proposed time average equation [2], Simmons (1964) gave the general linear relationship between the acoustic velocity and the component of rock and its density [3], Ma and Jie combined compressional wave velocity and shear wave velocity with density by least square method and proposed general Gardner Equation in 2005 [4], critical porosity was proposed by Nur et al. in 1992 [5], Han (1986) established empirical relationship for clasolite to describe the influence of lithology and physical properties on the acoustic velocity [6], Biot (1956) and Gassmann (1951) obtained the equation to describe the influence of fluid on the rock acoustic velocity [7] [8], many other equations are also established based on them to describe fluid effect (such as Macko-jizba Formula [9]), Garden (1974) proposed the power function relationship between the acoustic velocity and density [10], Gan (2002) [11] ,Ma and Wu (2006) [12], Mavko (1998) [13], Han and Nur (1986) also carried out the experiments to investigate the influence of pressure and temperature on the velocity and its physical mechanism. However, few researches are done on volcano clastic rock and there are not many related papers. Schön (1996) [14] did a lot of statistical work on the acoustic velocity data of igneous rock and found that, the compressional wave velocity decreases with the increase of $\mathrm{SiO}_{2}$ in the rock, Khatchikian(1982) [15] combined density, neutron and acoustic logging curves to determine the lithology of igneous rock and calculated the porosity of reservoirs.

The compressional and shear wave velocities of conglomerate and tuffaceous rock-fragment sandstone in Tanan were measured in this paper. The influences of lithology, mineral content, density, porosity, clay content and fluid saturation on the compressional and shear wave velocity are then analyzed, which provide the experimental foundation for employing seismic and logging data to predict the lithology, calculate porosity and recognize the fluid type.

\section{Geological Characteristics of Volcano Clastic Sandstone Reservoirs}

The core samples are obtained from Nantun Formation and Tongbomiao Formation of Cretaceous in Tanan. Through the thin section analysis, it shows that the core samples belong to tuffaceous conglomerate, tuffaceous rock-fragment sandstone and tuff. The sandstone is mainly composed of quartz, feldspar and magmatite debris, the void space in the sandstone is filled by tuff. The samples have low degree of sorting and the degree of weathering is moderate to high, the roundness of the grains is mainly subangular and subangular-subround. The samples are supported by grains or clay, the contact types between the grains are no contact to point contact and point contact to line contact, the porosity types belong to original granular porosity and granular increment porosity, the samples are pore cemented. Among the samples, the tuffaceous rock-fragment sandstone has better physical properties than the other samples (the average porosity is $9.96 \%$, the average permeability is $28.01 \mathrm{mD}$, the shale content is low), it is the main reservoir of this area. The tuffaceous conglomerate with better physical properties can also be the good reservoirs. Appendix 1 gives the results of thin section analysis.

\section{Experimental Methods}

\subsection{The Measurement of Porosity, Permeability, Clay Content and Density}

The porosity and permeability of samples are measured by CMS300 which is made by CORELAB Company of US. Under the simulated formation pressure ( effective pressure is $25 \mathrm{MPa}$ ), the average porosity of the samples ranges from $0.02 \%$ to $21.19 \%$, the average value is $6.21 \%$, the permeability is distributed between $0.01 \mathrm{mD}$ and $793 \mathrm{mD}$, the average value is $12.61 \mathrm{mD}$. The shale content is determined by MASTERSIZER-2000 Laser Particle Size Analyzer, the shale content ranges from $14.2 \%$ to $38.6 \%$, the average value is $24.18 \%$. The density of core samples is calculated using the mass of the core samples, the matrix volume and void space volume measured by CMS300. The measurement results are shown in Appendix 2.

$$
\rho=\frac{m}{V_{g}+V_{p o r}}
$$


where $\rho$ is the density, $\mathrm{g} / \mathrm{cm}^{3} ; \mathrm{m}$ is the mass of the samples; $V_{g}, V_{p o r}$ are matrix volume and void space volume respectively, $\mathrm{cm}^{3}$.

\subsection{Measurement of Acoustic Velocity}

The acoustic velocities of core samples are measured by Multi Parameter Measurement System Under HPHT made by China University of Petroleum (East China). The measurement system is showed in Figure 1(a). From the Figure 1(a), we can see that the system is composed of four parts: hydraulic pump, temperature control unit, sample length measurement unit (micro displacement sensor) and data acquisition (Figure 1(b)), the velocity of the core samples can be measured under the simulated formation temperature $\left(\leq 150^{\circ} \mathrm{C}\right)$, and pressure ( confining pressure, axle pressure and effective pressure $\leq 70 \mathrm{MPa}$ ). Ultrasonic Pulse Transmission Method is employed in the measurement of compressional and shear wave velocity. The acoustic velocity of the medium is calculated through the ratio of the length of transmission $L$ to the arrival time $t$ subtracted the system zero time $t_{0}$, i.e.

$$
V=L /\left(t-t_{0}\right)
$$

where $\mathrm{V}$ is the acoustic velocity, $\mathrm{m} / \mathrm{s} ; \mathrm{L}$ is the length of the core samples, $\mathrm{m}$; $\mathrm{t}$ is the arrival time of the sound wave; to is the zero time of the system, s. The frequencies of the wafers for compressional and shear wave are 1.2 MHZ and 0.6 MHZ, respectively. The frequencies of detectors for compressional and shear wave are 0.25 $\mathrm{MHZ}$ and $0.12 \mathrm{MHZ}$, respectively. The relative uncertainty for the measurement of compressional wave velocity is $0.3 \%-0.9 \%$, that for shear wave velocity is $0.8 \%-1.4 \%$. In this experiment, the compressional and shear wave velocities of the dry, brine bearing (the salinity is $5000 \mathrm{mg} / \mathrm{L}$ ) and oil bearing( the density of the simulated oil is $0.798 \mathrm{~g} / \mathrm{cm}^{3}$, the viscosity is $3.52 \mathrm{mPa}$ *s) samples are measured under the formation condition ( temperature is $90^{\circ} \mathrm{C}$, confining pressure is $50 \mathrm{MPa}$, the porosity pressure is $25 \mathrm{MPa}$ ). The measurement results are showed in Appendix 2.

\section{The Analysis of the Factors That Affect the Acoustic Velocity}

\subsection{The Influence of Mineral Content and Lithology on the Acoustic Velocity}

The influences of quartz, feldspar, magmatite debris and tuff on the compressional and shear wave velocities of dry core samples are presented in Figure 2. The lithology and mineral content are determined by thin section. The results show that the compressional and shear wave velocities decrease with the increase of the content of quartz and feldspar as a whole, but they increase as the content of magmatite debris increase. The content of tuff is found to have little relationship with the acoustic velocities. Among all the core samples, the velocities of the tight tuffaceous conglomerate are found to be obviously higher than those of the tuffaceous conglomerate and tuffaceous rock-fragment sandstones with good physical properties, through careful analysis, it is believed that it is mainly because of the low content of quartz $(\leq 10 \%)$ and high content of magmatite debris $(\geq 60 \%)$ in the tight tuffaceous conglomerate. Some of the data points in the Figure 2 do not fit the allover trend, it is maybe due to the different geometry, distribution, cementation of the minerals and the porosity between the mineral grains.
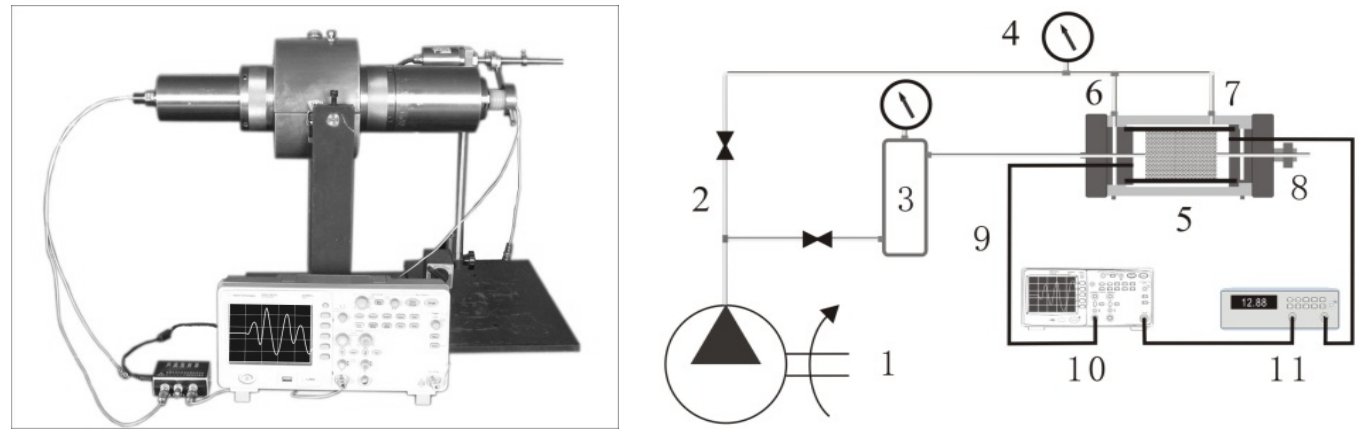

Figure 1. Sketch map of measurement system for acoustic parameters of core samples. 1-hydraulic pump; 2-fluid pipeline; 3-fluid container; 4-Pressure gauge; 5-hassler holder; 6-entry of Axial pressure; 7-entry of Central pressure; 8-Micro-displacement Sensor; 9-Acoustic data line; 10-Agilent Oscilloscope; 11 -Pulse generator. 


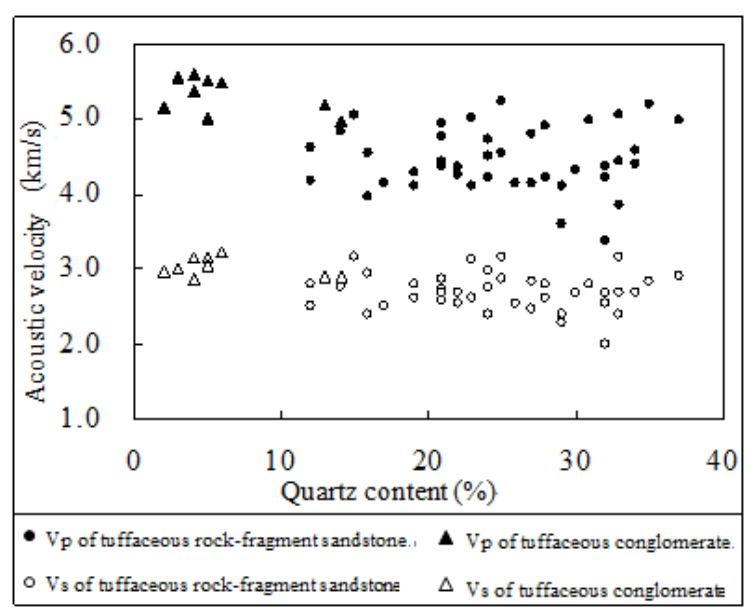

(a)

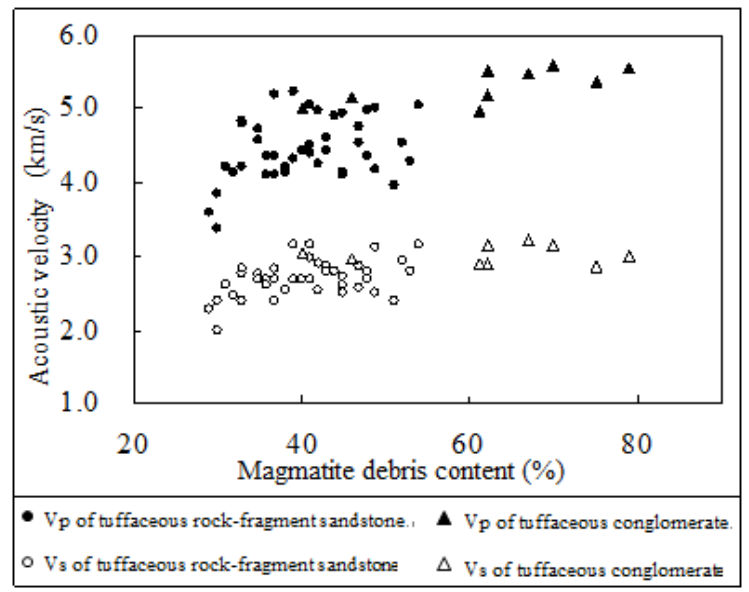

(c)

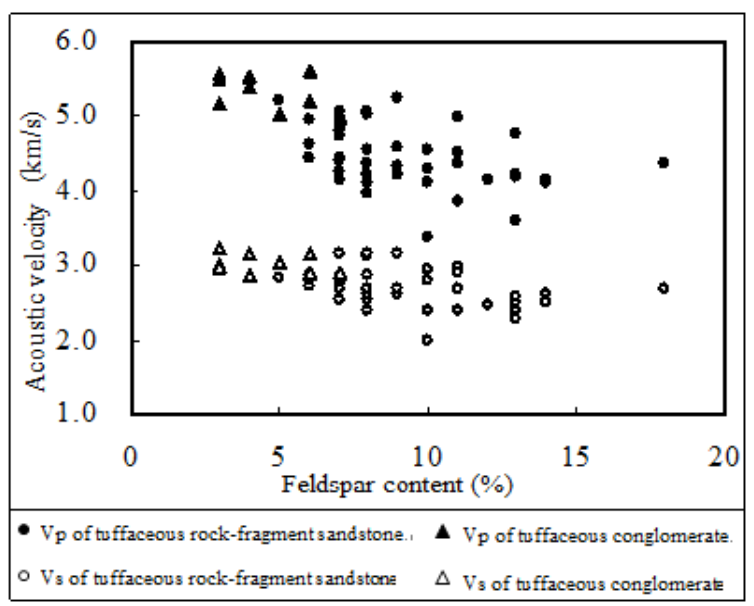

(b)

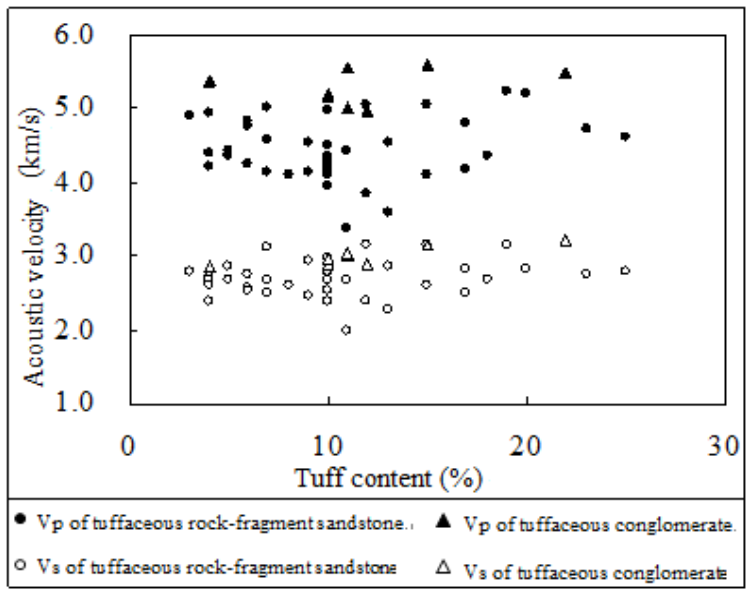

(d)

Figure 2. Compressional and shear wave velocities versus content of Quartz (a); Feldspar (b); Magmatic rock debris (c) and Tuffaceous miscellaneous base (d).

\subsection{The Influence of Density of Core Samples on the Velocities}

Figure 3 shows the cross-plot of the compressional and shear wave velocities versus the density of core samples $\rho$. The results show that the compressional and shear wave velocities of the core samples increase with their density. The data points with relative high compressional and shear wave velocities in Figure 3 are tuffaceous conglomerate (it is showed in the ellipse of the upper right side of Figure 3). The tuffaceous rock-fragment sandstones and tuffaceous conglomerate can be separated by the compressional velocities as a whole and the value is about $5300 \mathrm{~m} / \mathrm{s}$. Table 1 is the relationship between the density of tuffaceous rock-fragment sandstones $\rho$ and the acoustic velocities. It is found that the difference between the correlation coefficient of the fitting formula obtained from general Gardner Formula and that obtained from Gardenr Formula is not large, the former just improves a little. With the lack of shear wave velocities, we can only use compressional wave velocities to inverse the density $\rho$, it can also get good results. Ma and Xie (2005) also got similar results.

\subsection{The Influence of Porosity and Shale Content on the Acoustic Velocity}

Through the literature review [16]-[19], we can see that the compressional and shear wave velocities of samples decrease with the increase of porosity, the influence of shale content on the acoustic velocities is much more complicated, for the sandstone with good consolidation, the increase of clay content will lead to the decrease of acoustic velocities, but it will cause a slight increase in the acoustic velocities for the sandstone with weak consolidation. Generally speaking, the shale content is the leading reason for the scattering of the data points in the 


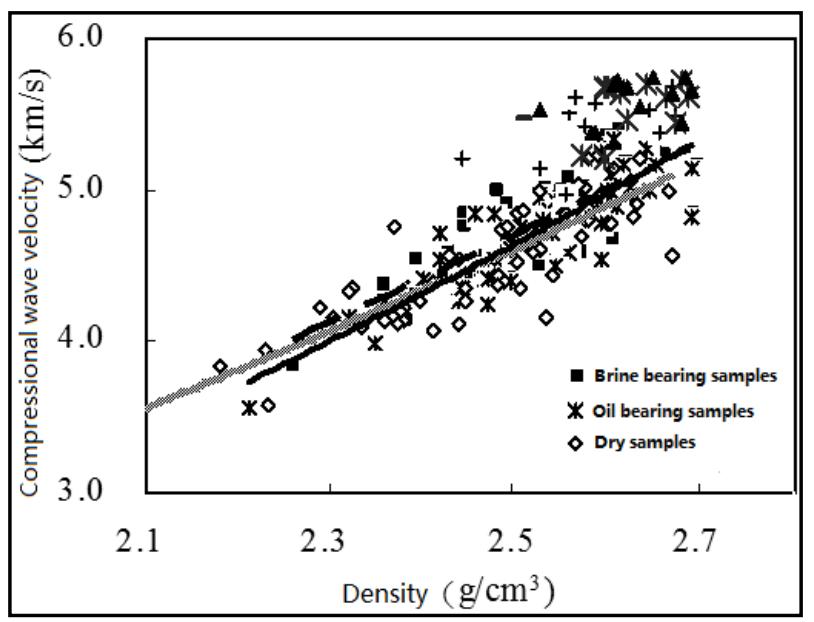

(a)

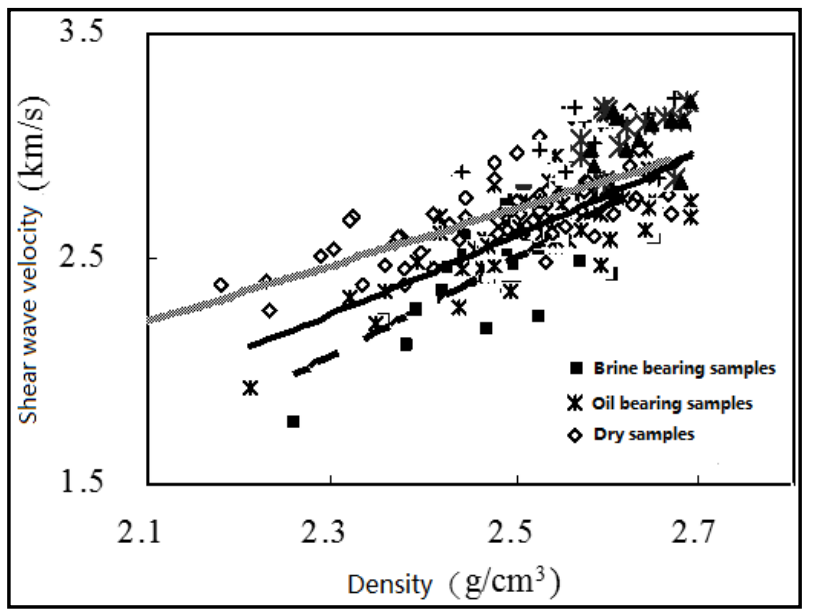

(b)

Figure 3. Compressional wave (a) and shear wave (b) velocities versus density.

Table 1. The fitting equation between density and compressional or shear wave velocities.

\begin{tabular}{ccccccc}
\hline $\begin{array}{c}\text { Status of } \\
\text { Samples }\end{array}$ & $\begin{array}{c}\text { Fitting } \\
\text { Formula }\left(\mathbf{V}_{\mathbf{p}}\right)\end{array}$ & Coefficient & Fitting Formula $\left(\mathbf{V}_{\mathbf{s}}\right)$ & Coefficient & General Gardner & Coefficient \\
\hline Dry & $\rho=1.095 V_{p}^{0.537}$ & $\mathrm{R}=0.86$ & $\rho=1.506 V_{s}^{0.482}$ & $\mathrm{R}=0.85$ & $\rho=1.218 V_{p}^{0.318} V_{s}^{0.222}$ & $\mathrm{R}=0.88$ \\
Brine bearing & $\rho=1.332 V_{p}^{0.408}$ & $\mathrm{R}=0.81$ & $\rho=1.995 V_{\mathrm{s}}^{0.246}$ & $\mathrm{R}=0.82$ & $\rho=1.697 V_{p}^{0.157} V_{s}^{0.158}$ & $\mathrm{R}=0.87$ \\
Oil bearing & $\rho=1.314 V_{p}^{0.418}$ & $\mathrm{R}=0.87$ & $\rho=1.839 V_{\mathrm{s}}^{0.314}$ & $\mathrm{R}=0.82$ & $\rho=1.306 V_{p}^{0.427} V_{s}^{0.006}$ & $\mathrm{R}=0.87$ \\
\hline
\end{tabular}

Note: The unit for acoustic velocity is $\mathrm{m} / \mathrm{s}$, that for the density of the samples is $\mathrm{g} / \mathrm{cm}^{3}$.

velocity-porosity cross-plot. According to the linear empirical relationship gave by Han (1986) [20], the relationship between the compressional and shear wave velocities and the porosity-shale content is fitted (Table 2).

$$
V=a+b \varphi+c V_{s h}
$$

where $\mathrm{V}$ is the acoustic velocity, $\mathrm{km} / \mathrm{s} ; \phi$ is the porosity of the samples, $\% ; V_{s h}$ is the shale content of samples, $\% ; a 、 b 、 c$ are the constants obtained by the experiments.

The study shows that there is an obvious negative linear correlation between tuffaceous rock-fragment sandstone and the porosity, shale content $(\mathrm{R} \geq 0.85)$, the influence of shale content on the compressional and shear 
Table 2. Fitting formula of density and compressional and shear wave velocities on porisity and clay content.

\begin{tabular}{ccc}
\hline Status & Expression & Correlation coefficient \\
\hline \multirow{2}{*}{ Dry sample } & $V_{p}=5.12-6.98 \varphi-0.4 V_{s h}$ & $\mathrm{R}=0.86$ \\
& $V_{s}=3.33-4.91 \varphi-0.82 V_{s h}$ & $\mathrm{R}=0.87$ \\
Brine bearing & $V_{p}=5.45-6.12 \varphi-0.5 V_{s h}$ & $\mathrm{R}=0.87$ \\
& $V_{s}=3.28-5.7 \varphi-0.75 V_{s h}$ & $\mathrm{R}=0.89$ \\
Oil bearing & $V_{p}=5.46-7.18 \varphi-0.65 V_{s h}$ & $\mathrm{R}=0.90$ \\
& $V_{s}=3.31-5.1 \varphi-0.83 V_{s h}$ & $\mathrm{R}=0.88$ \\
\hline
\end{tabular}

wave velocities is only about $1 / 5-1 / 10$ of that of porosity. Therefore, the influence of shale content on acoustic velocities is very weak and can be ignored. This result is different from Han's which is based on the experimental data from 75 shale sandstone samples in Gulf of Mexico, his result shows that the influence of shale content is about $1 / 3$ of that of porosity. Through careful analysis, the main reason for the difference may be that the shale in the volcanic clastic rock is mainly composed of tuff, the main component of tuff is volcanic debris, whose acoustic velocity is much higher than that of clay and is near to that of matrix, this will weaken the influence of shale content to a certain degree. Until now, there are only experimental results for the tuffaceous rockfragment sandstone in the cretaceous of Haita Basin,it needs further research on this aspect.

\subsection{The Influence of Pore Fluid on the Acoustic Velocity}

The influence of pore fluid on the acoustic velocity is investigated through fluid substitution. The theories usually used in the analysis are Biot Theory and Gassman Equation. The difference in compressional and shear wave velocities between brine-bearing and oil-bearing versus porosity is showed in Figure 4.

From Figure 4, we can see that the absolute value of the difference in compressional and shear wave velocities between brine-bearing and oil-bearing samples increases with the porosity. The compressional wave velocity of brine-bearing samples is higher than that of oil-bearing, the absolute change rate ranges from $0-300 \mathrm{~m} / \mathrm{s}$, the relative change rate (relative to the compressional velocities of oil-bearing samples) is near $6 \%$ at most, the samples are sensitive to the fluid substitution. The shear wave velocities of the brine-bearing samples are relative small than that of oil-bearing samples, the absolute change rate ranges from $0-120 \mathrm{~m} / \mathrm{s}$, the relative change rate is small, the response of fluid substitution is not obvious.

According to Biot Theory and Gassmann Equation, the change of compressional velocity after fluid substitution is mainly because of the difference in the bulk modulus of the fluid, the bulk modulus of the water is higher than that of the oil, so the brine-bearing core samples have higher velocities than the oil-bearing core samples. For the change of the shear wave velocities, Wang and Nur (1986) attributed it to the change of the density and viscosity in the samples. As the fluid substitution won't cause obvious change in the shear modulus, the decrease of the density or the increase of viscosity will both increase the shear wave velocity.

\section{Conclusion and Discussion}

The research is done to investigate the influence of lithology, mineral content, density, porosity, shale content and fluid saturation on the compressional and shear wave velocities, the following conclusions can be obtained.

1) The compressional and shear wave velocities increase with increase of the content of magmatite debris, but they decrease with the increase of quartz and feldspar content. It is due to the difference in elastic modulus and density between magmatite and quartz, feldspar.

2) Tight tuffaceous conglomerate has low content of quartz $(\leq 10 \%)$ and high content of magmatite debris $(\geq 60 \%)$, its velocity is obviously higher than the tuffaceous rock-fragment sandstone with good physical properties. We can use $5300 \mathrm{~m} / \mathrm{s}$ as the lower velocity bound to separate the compressional velocity of tight tuffaceous conglomerate and tuffacous rock-fragment sandstone.

3) The compressional and shear wave velocities increase with the increase of density. There is a good power relationship between the acoustic velocity and the density. In the seismic and logging evaluation work, the power statistic relationship established by experiments can be applied to predict the shear wave velocity and 


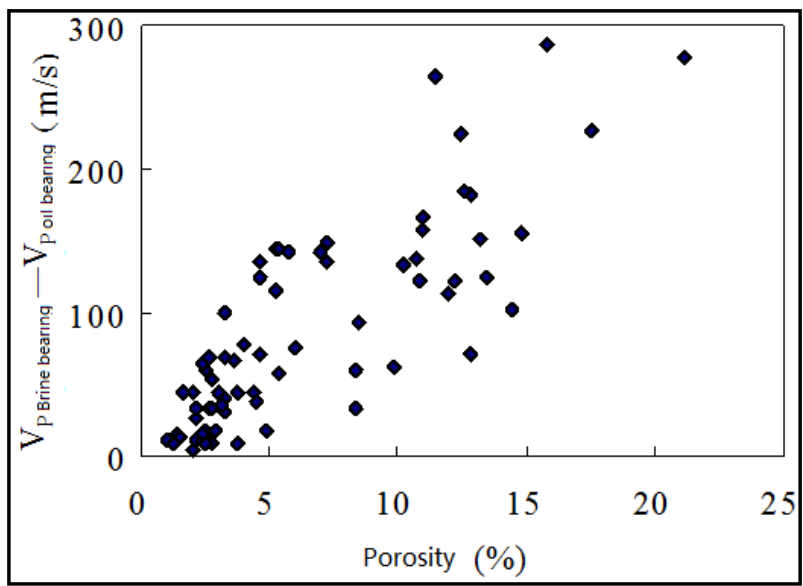

(a)

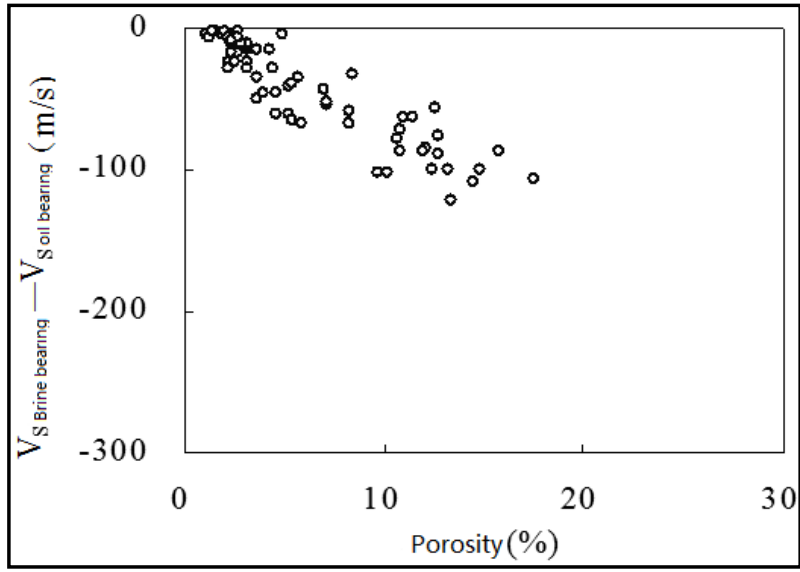

(b)

Figure 4. Difference in compressional wave (a) and Shear wave (b) Velocities between brine-bearing and oil-bearing one Versus Porosity.

reestablish the density logging curve.

4) The compressional and shear wave decrease when the porosity or the shale content increase, the acoustic velocity of tuffaceous rock-fragment sandstone has good negative linear relationship with the porosity and shale content. The influence of shale content on the acoustic velocity is only $1 / 5-1 / 10$ of that of porosity, which may be related to the tuff shale in the samples. Therefore, when calculating the porosity of the reservoir in cretaceous of Haita, the influence of shale can be ignored.

5) The increase of water saturation will lead to the increase of compressional velocity and the slight decrease of shear wave velocity. The change of acoustic velocity is positive related to the porosity, but the largest change can't exceed 6\%. Therefore, if the compressional and shear wave velocities obtained from the seismic and logging data has low uncertainty, it is possible to use the seismic and logging data to recognize the oil and gas reservoirs with good physical properties.

\section{References}

[1] Wu, Y., Chen, J.L. and Zhang, Y. (2009) Relationships between Different Types of Structural Zones and Hydrocarbons in Hailaer-Tamtsag Basin. Journal of Daqing Petroleum Institute, 33, 31-35. http://en.cnki.com.cn/Article en/CJFDTotal-DQSY200903010.htm

[2] Wyllie, M.R.J., Gregory, A.R. and Gardner, L.W. (1956) Elastic Wave Velocities in Heterogeneous and Porous Media. GEOPHYSICS, 41-70. http://dx.doi.org/10.1190/1.1438217

[3] Simmons, G. (1964) Velocity of Compressional Waves in Various Minerals at Pressure to 10 Kbars. Journal of Geo- 
physical Research, 69, 1117-1121. http://dx.doi.org//10.1029/JZ069i006p01117/pdf

[4] Ma, Z.G. and Xie, J.G. (2005) Relationship among Compressional Wave, Shear Wave Velocities and Density of Rocks. Progress in Geophysics (in Chinese), 20, 905-910. http://dx.doi.org/10.1190/1.1441933

[5] Nur, A. (1992) Critical Porosity and the Seismic Velocity in Rocks. EOS Trans Am Geophys Union, 73, 43-66. http://dx.doi.org/10.1190/1.1437977

[6] Han, D., Nur, A. and Morgan, D. (1986) Effects of Porosity and Clay Content on Acoustic Properties of Sandstones and Unconsolidated Sediments. GEOPHYSICS, 51, 2093-2107. http://dx.doi.org/10.1190/1.1442062

[7] Biot, M.A. (1956) Theory of Propagation of Elastic Waves in A Fluid Saturated Porous Solid, I: Low Frequency Range, and II: Higher-frequency Range. Journal of the Acoustical Society of America, 168-196.

http://dx.doi.org/10.1121/1.1908241

[8] Gassmann, F. (1951) Elastic Waves through a Packing of Spheres. GEOPHYSICS, 16, 673-685. http://dx.doi.org/10.1190/1.1437718

[9] Mavko, G. and Jizba, D. (1991) Estimating Grain-Scale Fluid Effects on Velocity Dispersion in Rock. GEOPHYSICS, 56, 1940-1949. http://dx.doi.org/10.1190/1.1443005

[10] Gardner, G.H.F., Gardner, L.W. and Gregory, A.R. (1974) Formation Velocity and Density-The Diagnostic Basics for Stratigraphic Traps. GEOPHYSICS, 39, 770-780. http://dx.doi.org/10.1190/1.1440465

[11] Gan, L.D. (2002) 4D Seismic and Its Application to the Monitoring of Water Flooding Reservoir. Ph.D. Thesis, China University of Geosciences (in Chinese), Beijing.

[12] Ma, Z.G. and Wu, X.Y. (2006) Effects of Effective Pressure on Wave Velocities on Rocks. Progress in Exploration Geophsics (in Chinese), 29, 183-186. http:/www.cnki.com.cn/Article/CJFDTotal-KTDQ200603006.htm

[13] Mavko, G., Mukerji, T. and Dvorkin, J. (1998) The Rock Physics Handbook: Tools for Seismic Analysis in Porous Media. Cambridge University Press, 208-210

[14] Schön, J.H. (1996) Physical Properties of Rock: Fundamentals and Principles of Petrophysics. Ultrasonic, 311-317. http://dx.doi.org/10.1029/97EO00363

[15] Khatchikian, A. (1982) Log Evaluation of Oil-Bearing Igneous Rocks. 23th SPWLA Annual Logging Symposium Transactions, Texas, 6-9 July, AA. https://www.onepetro.org/conference-paper/SPWLA-1982-AA

[16] Wang, B.Z. (2008) Seismic Rock Physics and Its Applied Research. Ph.D. Thesis, Chengdu University of Science and Technology (in Chinese), Chengdu.

[17] Shi, G. and Yang, D.Q. (2001) The Regression Analysis Study on Velocity and Porosity and Clay Content of Rocks. Acta Scicentiarum Naturalum Universitis Pekinesis (in Chinese), 37, 379-384. http://dx.doi.org/10.3321/j.issn:0479-8023.2001.03.015

[18] Klimentos, T. (1991) The Effects of Porosity-Permeability-Clay Content on the Velocity of Compressional Waves. GEOPHYSICS, 56, 1930-1939. http://dx.doi.org/10.1190/1.1443004

[19] Dvorkin, J., Mavko, G. and Nur, A. (1995) Squirt Flow in Fully Saturated Rocks. GEOPHYSICS, 60, 97-107. http://dx.doi.org/10.1190/1.1443004

[20] Han, D., Nur, A. and Morgan, D. (1986) Effects of Porosity and Clay Content on Wave Velocities in Sandstones. GEOPHYSICS, 51, 2093-2107. http://dx.doi.org/10.1190/1.1442062 
Appendix 1: The Date of Thin Section Analysis in Rocks.

\begin{tabular}{|c|c|c|c|c|c|c|c|c|c|c|}
\hline \multirow{3}{*}{$\begin{array}{l}\text { Sample } \\
\text { No. }\end{array}$} & \multirow{3}{*}{$\begin{array}{c}\text { Quartz } \\
(\%)\end{array}$} & \multirow{3}{*}{$\begin{array}{c}\text { Feldspar } \\
(\%)\end{array}$} & \multicolumn{2}{|c|}{ Debris } & \multicolumn{5}{|c|}{ Fillings } & \multirow{3}{*}{ Denomination } \\
\hline & & & \multirow{2}{*}{$\begin{array}{c}\begin{array}{c}\text { Sedimentary } \\
\text { rock }\end{array} \\
(\%)\end{array}$} & \multirow{2}{*}{$\begin{array}{c}\text { Magmatite } \\
(\%)\end{array}$} & \multirow{2}{*}{$\begin{array}{c}\text { Shale } \\
(\%)\end{array}$} & \multirow{2}{*}{$\begin{array}{l}\text { Tuff } \\
(\%)\end{array}$} & \multirow{2}{*}{$\begin{array}{c}\text { Calcspar } \\
(\%)\end{array}$} & \multirow{2}{*}{$\begin{array}{c}\text { Carbonate } \\
(\%)\end{array}$} & \multirow{2}{*}{$\frac{\text { Silica }}{(\%)}$} & \\
\hline & & & & & & & & & & \\
\hline 4 & 34 & 9 & & 35 & & 7 & 2 & 4 & 1 & $\begin{array}{c}\text { Tuffaceous rock-fragment } \\
\text { sandstone }\end{array}$ \\
\hline 5 & 14 & 7 & 3 & 33 & 33 & 6 & & & & $\begin{array}{c}\text { Tuffaceous rock-fragment } \\
\text { sandstone }\end{array}$ \\
\hline 6 & 19 & 10 & & 53 & & 10 & 1 & & & $\begin{array}{c}\text { Tuffaceous rock-fragment } \\
\text { sandstone }\end{array}$ \\
\hline 8 & 24 & 13 & & 33 & & 4 & & 10 & & $\begin{array}{c}\text { Tuffaceous rock-fragment } \\
\text { sandstone }\end{array}$ \\
\hline 9 & 17 & 14 & & 45 & & 7 & & & 1 & $\begin{array}{c}\text { Tuffaceous rock-fragment } \\
\text { sandstone }\end{array}$ \\
\hline 10 & 23 & 14 & & 36 & & 8 & 2 & 5 & & $\begin{array}{c}\text { Tuffaceous rock-fragment } \\
\text { sandstone }\end{array}$ \\
\hline 11 & 28 & 9 & 4 & 31 & 16 & 4 & & & & $\begin{array}{c}\text { Tuffaceous rock-fragment } \\
\text { sandstone }\end{array}$ \\
\hline 14 & 31 & 7 & & 48 & & 10 & & & & $\begin{array}{c}\text { Tuffaceous rock-fragment } \\
\text { sandstone }\end{array}$ \\
\hline 15 & 5 & 4 & & 62 & 8 & & 18 & & & Tuffaceous conglomerate \\
\hline 16 & 24 & 11 & & 41 & & 10 & 7 & & 2 & $\begin{array}{c}\text { Tuffaceous rock-fragment } \\
\text { sandstone }\end{array}$ \\
\hline 17 & 33 & 8 & & 41 & & 12 & & 2 & & $\begin{array}{c}\text { Tuffaceous rock-fragment } \\
\text { sandstone }\end{array}$ \\
\hline 18 & 25 & 9 & & 39 & & 19 & 3 & & 1 & $\begin{array}{c}\text { Tuffaceous rock-fragment } \\
\text { sandstone }\end{array}$ \\
\hline 19 & 23 & 8 & & 49 & & 7 & 7 & & 1 & $\begin{array}{c}\text { Tuffaceous rock-fragment } \\
\text { sandstone }\end{array}$ \\
\hline 20 & 4 & 6 & & 70 & & 15 & & & & Tuffaceous conglomerate \\
\hline 23 & 16 & 8 & & 51 & & 10 & & & 2 & $\begin{array}{c}\text { Tuffaceous rock-fragment } \\
\text { sandstone }\end{array}$ \\
\hline 24 & 19 & 8 & & 45 & & 15 & & 3 & & $\begin{array}{c}\text { Tuffaceous rock-fragment } \\
\text { sandstone }\end{array}$ \\
\hline 30 & 2 & 3 & & 46 & & 10 & 4 & & & Tuffaceous conglomerate \\
\hline 31 & 34 & 7 & & 41 & & 4 & & 6 & & $\begin{array}{c}\text { Tuffaceous rock-fragment } \\
\text { sandstone }\end{array}$ \\
\hline 32 & 29 & 10 & & 37 & 2 & 10 & & & 1 & $\begin{array}{c}\text { Tuffaceous rock-fragment } \\
\text { sandstone }\end{array}$ \\
\hline 33 & 28 & 7 & & 44 & & 3 & 14 & & & $\begin{array}{c}\text { Tuffaceous rock-fragment } \\
\text { sandstone }\end{array}$ \\
\hline 35 & 12 & 13 & & 49 & & 17 & & & & $\begin{array}{c}\text { Tuffaceous rock-fragment } \\
\text { sandstone }\end{array}$ \\
\hline 36 & 15 & 7 & & 54 & & 15 & 2 & & & $\begin{array}{c}\text { Tuffaceous rock-fragment } \\
\text { sandstone }\end{array}$ \\
\hline 37 & 37 & 11 & & 42 & 6 & & 2 & & & $\begin{array}{c}\text { Tuffaceous rock-fragment } \\
\text { sandstone }\end{array}$ \\
\hline 38 & 33 & 11 & & 30 & & 12 & & & 2 & $\begin{array}{c}\text { Tuffaceous rock-fragment } \\
\text { sandstone }\end{array}$ \\
\hline
\end{tabular}


Continued

\begin{tabular}{|c|c|c|c|c|c|c|c|c|c|c|}
\hline 41 & 21 & 18 & & 37 & & 5 & & 10 & & $\begin{array}{c}\text { Tuffaceous rock-fragment } \\
\text { sandstone }\end{array}$ \\
\hline 42 & 29 & 13 & 1 & 29 & & 13 & & & 2 & $\begin{array}{c}\text { Tuffaceous rock-fragment } \\
\text { sandstone }\end{array}$ \\
\hline 44 & 35 & 5 & & 37 & & 20 & & & & $\begin{array}{c}\text { Tuffaceous rock-fragment } \\
\text { sandstone }\end{array}$ \\
\hline 46 & 22 & 7 & & 42 & & 6 & 3 & & & $\begin{array}{c}\text { Tuffaceous rock-fragment } \\
\text { sandstone }\end{array}$ \\
\hline 47 & 16 & 10 & & 52 & & 9 & & 1 & & $\begin{array}{c}\text { Tuffaceous rock-fragment } \\
\text { sandstone }\end{array}$ \\
\hline 48 & 26 & 7 & & 38 & & 10 & & & & $\begin{array}{c}\text { Tuffaceous rock-fragment } \\
\text { sandstone }\end{array}$ \\
\hline 49 & 21 & 13 & & 47 & & 6 & & & 2 & $\begin{array}{c}\text { Tuffaceous rock-fragment } \\
\text { sandstone }\end{array}$ \\
\hline 50 & 32 & 8 & & 38 & & 10 & & & 1 & $\begin{array}{c}\text { Tuffaceous rock-fragment } \\
\text { sandstone }\end{array}$ \\
\hline 51 & 13 & 6 & & 62 & & 10 & & & 2 & Tuffaceous conglomerate \\
\hline 52 & 30 & 9 & & 39 & & 10 & & & 1 & $\begin{array}{c}\text { Tuffaceous rock-fragment } \\
\text { sandstone }\end{array}$ \\
\hline 53 & 32 & 11 & & 36 & & 10 & & & 2 & $\begin{array}{c}\text { Tuffaceous rock-fragment } \\
\text { sandstone }\end{array}$ \\
\hline 55 & 6 & 3 & & 67 & & 22 & & & & Tuffaceous conglomerate \\
\hline 58 & 12 & 6 & 1 & 43 & & 25 & & & & $\begin{array}{c}\text { Tuffaceous rock-fragment } \\
\text { sandstone }\end{array}$ \\
\hline 59 & 21 & 6 & 3 & 43 & & 5 & 4 & 5 & & $\begin{array}{c}\text { Tuffaceous rock-fragment } \\
\text { sandstone }\end{array}$ \\
\hline 60 & 14 & 7 & & 61 & & 12 & & & & Tuffaceous conglomerate \\
\hline 61 & 33 & 7 & & 40 & & 11 & 2 & & & $\begin{array}{c}\text { Tuffaceous rock-fragment } \\
\text { sandstone }\end{array}$ \\
\hline 62 & 24 & 7 & 3 & 35 & 5 & 23 & & & & $\begin{array}{c}\text { Tuffaceous rock-fragment } \\
\text { sandstone }\end{array}$ \\
\hline 65 & 27 & 12 & 3 & 32 & & 9 & & & & $\begin{array}{c}\text { Tuffaceous rock-fragment } \\
\text { sandstone }\end{array}$ \\
\hline 66 & 32 & 10 & & 30 & & 11 & 2 & & & $\begin{array}{c}\text { Tuffaceous rock-fragment } \\
\text { sandstone }\end{array}$ \\
\hline 67 & 3 & 3 & & 79 & & 11 & & & & Tuffaceous conglomerate \\
\hline 68 & 4 & 4 & & 75 & & 4 & 5 & & & Tuffaceous conglomerate \\
\hline 72 & 27 & 7 & 4 & 33 & 8 & 17 & & & & $\begin{array}{c}\text { Tuffaceous rock-fragment } \\
\text { sandstone }\end{array}$ \\
\hline 73 & 21 & 6 & & 45 & & 4 & 15 & 6 & & $\begin{array}{c}\text { Tuffaceous rock-fragment } \\
\text { sandstone }\end{array}$ \\
\hline 74 & 22 & 8 & & 48 & & 18 & & & & $\begin{array}{c}\text { Tuffaceous rock-fragment } \\
\text { sandstone }\end{array}$ \\
\hline 75 & 25 & 8 & & 47 & & 13 & 3 & & & $\begin{array}{c}\text { Tuffaceous rock-fragment } \\
\text { sandstone }\end{array}$ \\
\hline
\end{tabular}


Appendix 2: The Date of Physical Parameters and Compressional and Shear Wave Velocities in Rocks.

\begin{tabular}{|c|c|c|c|c|c|c|c|c|c|}
\hline \multirow{3}{*}{ Sample No. } & \multicolumn{2}{|c|}{ Dry sample } & \multicolumn{2}{|c|}{ Oil-bearing sample } & \multicolumn{2}{|c|}{ Brine-bearing sample } & \multirow{2}{*}{ Porosity } & \multirow{2}{*}{ Shale } & \multirow{2}{*}{ Permeability } \\
\hline & $V p$ & $V s$ & $V p$ & $V s$ & $V p$ & $V s$ & & & \\
\hline & $(\mathrm{km} / \mathrm{s})$ & $(\mathrm{km} / \mathrm{s})$ & $(\mathrm{km} / \mathrm{s})$ & $(\mathrm{km} / \mathrm{s})$ & $(\mathrm{km} / \mathrm{s})$ & $(\mathrm{km} / \mathrm{s})$ & $(\%)$ & $(\%)$ & $(\mathrm{mD})$ \\
\hline 4 & 4.56 & 2.66 & 4.76 & 2.64 & 4.82 & 2.54 & 9.78 & 21.42 & 0.17 \\
\hline 5 & 4.85 & 2.75 & 4.97 & 2.71 & 5.01 & 2.70 & 3.15 & 31.93 & 0.01 \\
\hline 6 & 4.27 & 2.78 & 4.62 & 2.75 & 4.65 & 2.69 & 8.29 & 21.83 & 0.03 \\
\hline 8 & 4.21 & 2.39 & 4.39 & 2.35 & 4.49 & 2.24 & 14.47 & 18.07 & 1.76 \\
\hline 9 & 4.13 & 2.48 & 4.40 & 2.45 & 4.58 & 2.37 & 12.78 & 23.28 & 1.50 \\
\hline 10 & 4.12 & 2.59 & 4.51 & 2.55 & 4.58 & 2.48 & 12.78 & 19.79 & 1.05 \\
\hline 11 & 4.21 & 2.61 & 4.42 & 2.58 & 4.69 & 2.52 & 11.42 & 24.08 & 0.32 \\
\hline 14 & 4.99 & 2.78 & 5.13 & 2.75 & 5.17 & 2.73 & 3.22 & 21.01 & 0.09 \\
\hline 15 & 5.53 & 3.15 & 5.62 & 3.13 & 5.63 & 3.11 & 2.31 & 29.52 & 0.10 \\
\hline 16 & 4.51 & 2.98 & 4.94 & 2.96 & 5.08 & 2.90 & 5.25 & 20.20 & 0.05 \\
\hline 17 & 5.04 & 3.17 & 5.25 & 3.14 & 5.35 & 3.12 & 3.19 & 25.70 & 0.01 \\
\hline 18 & 5.22 & 3.14 & 5.35 & 3.11 & 5.40 & 3.11 & 2.50 & 22.64 & 0.01 \\
\hline 19 & 5.00 & 3.13 & 5.29 & 3.10 & 5.34 & 3.09 & 4.33 & 24.31 & 0.03 \\
\hline 20 & 5.61 & 3.17 & 5.68 & 3.16 & 5.72 & 3.13 & 4.42 & 28.35 & 0.16 \\
\hline 21 & 5.52 & 3.18 & 5.69 & 3.16 & 5.70 & 3.16 & 4.90 & 32.60 & 0.29 \\
\hline 22 & 5.42 & 3.11 & 5.47 & 3.09 & 5.54 & 3.03 & 5.91 & 24.50 & 0.05 \\
\hline 23 & 3.95 & 2.40 & 4.26 & 2.36 & 4.55 & 2.28 & 15.75 & 23.49 & 96.96 \\
\hline 24 & 4.11 & 2.60 & 4.41 & 2.55 & 4.53 & 2.47 & 12.15 & 30.96 & 0.04 \\
\hline 26 & 4.68 & 2.72 & 4.79 & 2.69 & 4.84 & 2.69 & 2.69 & 38.97 & 0.01 \\
\hline 28 & 5.00 & 3.04 & 5.22 & 3.02 & 5.37 & 2.99 & 5.36 & 30.14 & 0.08 \\
\hline 30 & 5.14 & 2.98 & 5.24 & 2.95 & 5.38 & 2.92 & 5.68 & 29.01 & 0.20 \\
\hline 31 & 4.39 & 2.69 & 4.61 & 2.69 & 4.74 & 2.61 & 10.68 & 24.74 & 0.38 \\
\hline 32 & 4.10 & 2.38 & 4.26 & 2.29 & 4.41 & 2.19 & 13.23 & 23.53 & 0.81 \\
\hline 33 & 4.92 & 2.78 & 5.08 & 2.76 & 5.11 & 2.74 & 2.58 & 22.47 & 0.03 \\
\hline 34 & 4.83 & 2.74 & 4.99 & 2.73 & 4.99 & 2.72 & 2.04 & 39.36 & 0.02 \\
\hline 35 & 4.16 & 2.48 & 4.53 & 2.48 & 4.68 & 2.42 & 7.18 & 30.01 & 0.03 \\
\hline 36 & 5.05 & 3.16 & 5.16 & 3.14 & 5.23 & 3.11 & 3.62 & 26.45 & 0.00 \\
\hline 37 & 4.96 & 2.91 & 5.17 & 2.90 & 5.24 & 2.89 & 2.63 & 24.20 & 0.00 \\
\hline 38 & 3.84 & 2.39 & 4.16 & 2.33 & 4.38 & 2.23 & 17.55 & 25.57 & 1.83 \\
\hline 41 & 4.34 & 2.68 & 4.63 & 2.63 & 4.76 & 2.55 & 10.82 & 21.13 & 0.45 \\
\hline 42 & 3.58 & 2.27 & 3.98 & 2.22 & 4.13 & 2.12 & 14.77 & 26.97 & 0.88 \\
\hline 43 & 4.06 & 2.46 & 4.35 & 2.45 & 4.42 & 2.41 & 4.00 & 47.66 & 0.02 \\
\hline
\end{tabular}


L. L. Li et al.

Continued

\begin{tabular}{|c|c|c|c|c|c|c|c|c|c|}
\hline 44 & 5.21 & 2.82 & 5.26 & 2.80 & 5.27 & 2.79 & 2.35 & 26.74 & 0.01 \\
\hline 45 & 4.77 & 2.63 & 4.80 & 2.62 & 4.94 & 2.59 & 4.55 & 32.66 & 0.02 \\
\hline 46 & 4.26 & 2.53 & 4.54 & 2.48 & 4.67 & 2.37 & 10.17 & 24.19 & 0.71 \\
\hline 47 & 4.55 & 2.93 & 4.86 & 2.85 & 5.00 & 2.80 & 7.24 & 26.38 & 0.31 \\
\hline 48 & 4.15 & 2.54 & 4.41 & 2.51 & 4.59 & 2.46 & 12.61 & 15.57 & 1.72 \\
\hline 49 & 4.75 & 2.58 & 4.84 & 2.54 & 5.00 & 2.48 & 10.94 & 34.13 & 8.07 \\
\hline 50 & 4.21 & 2.52 & 4.32 & 2.48 & 4.44 & 2.36 & 13.46 & 20.16 & 1.63 \\
\hline 51 & 5.20 & 2.88 & 5.46 & 2.81 & 5.52 & 2.75 & 8.36 & 25.58 & 2.25 \\
\hline 52 & 4.32 & 2.67 & 4.54 & 2.62 & 4.76 & 2.52 & 12.45 & 17.68 & 10.46 \\
\hline 53 & 4.35 & 2.69 & 4.72 & 2.69 & 4.83 & 2.60 & 11.98 & 18.91 & 0.59 \\
\hline 55 & 5.50 & 3.21 & 5.62 & 3.21 & 5.67 & 3.20 & 1.57 & 23.91 & 0.01 \\
\hline 57 & 4.92 & 2.79 & 5.10 & 2.79 & 5.11 & 2.73 & 3.69 & 27.84 & 0.20 \\
\hline 58 & 4.61 & 2.78 & 4.88 & 2.75 & 4.95 & 2.72 & 3.18 & 29.90 & 0.01 \\
\hline 59 & 4.43 & 2.85 & 4.72 & 2.81 & 4.81 & 2.78 & 8.47 & 21.62 & 0.05 \\
\hline 60 & 4.96 & 2.88 & 5.20 & 2.84 & 5.32 & 2.80 & 5.20 & 26.18 & 0.24 \\
\hline 61 & 4.44 & 2.68 & 4.68 & 2.63 & 4.82 & 2.59 & 7.00 & 20.64 & 0.09 \\
\hline 62 & 4.74 & 2.74 & 4.94 & 2.71 & 4.95 & 2.71 & 2.71 & 29.29 & 0.02 \\
\hline 65 & 4.13 & 2.45 & 4.24 & 2.43 & 4.41 & 2.35 & 10.93 & 38.64 & 0.81 \\
\hline 66 & 3.38 & 1.99 & 3.56 & 1.93 & 3.84 & 1.78 & 21.19 & 14.19 & 793.4 \\
\hline 67 & 5.58 & 3.02 & 5.63 & 3.01 & 5.68 & 2.99 & 3.70 & 23.17 & 1.78 \\
\hline 68 & 5.38 & 2.86 & 5.44 & 2.86 & 5.45 & 2.85 & 2.16 & 29.38 & 0.03 \\
\hline 70 & 4.58 & 2.67 & 4.72 & 2.63 & 4.76 & 2.62 & 2.94 & 34.47 & 0.90 \\
\hline 72 & 4.81 & 2.84 & 4.99 & 2.81 & 5.02 & 2.79 & 2.76 & 25.07 & 0.01 \\
\hline 73 & 4.93 & 2.70 & 5.14 & 2.64 & 5.26 & 2.59 & 4.60 & 29.09 & 0.02 \\
\hline 74 & 4.35 & 2.69 & 4.71 & 2.67 & 4.79 & 2.61 & 4.58 & 25.66 & 0.02 \\
\hline 75 & 4.53 & 2.87 & 4.84 & 2.83 & 4.90 & 2.76 & 5.36 & 25.40 & 0.01 \\
\hline
\end{tabular}

